\title{
光インタコネクション特集に寄せて
}

\author{
桂 浩輔*
}

\section{Foreword to Special Issue on Optical Interconnection}

Kosuke KATSURA*

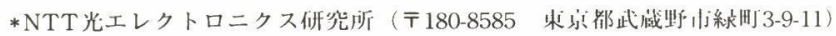

*NTT, Opto-electronics Laboratories (3-9-11 Midori-cho, Musashino-shi, Tokyo 180-8585)

マルチメディア時代の情報量の増大に対し，これらの情 報を処理する大容量ATM交換機や超並列コンピュータ等 の大規模システム, さらにはLAN等の小規模システムに 至るまで, システム処理能力の飛躍的な向上が期待されて います。一方, 高速高集積LSIや高密度実装技術の進歩に 伴い, これらLSIを搭載した配線ボードの入出力スループ ットは著しく増大し, 従来の電気信号配線では実装密度, システム性能向上のボトルネックとなりつつあります。こ の配線ボトルネックを解消する技術として, 今, 光インタ コネクションが脚光を浴びつつあります。一般に光通信装 置は, 製造コストが高く, 特に光実装では, 光の接続の悠 しさをいかに乗り越えるか, すなわち発光素子や受光素子 と光ファイバや光導波路などの微小光部品とのミクロンノ サブミクロンオーダの高精度な位置合わせが必須となりま す。この光接続の綮しさのゆえに, 光装置の実装において は, 現行の電気製品に用いられる量産性の良い製造プロセ スの適用を困難にしており, 装置コストの大半を実装コス トが占めているのが現状であります。すなわち光デバイス の実装技術は，現在，工業的にはまだまだ家内製手工業の 域を出ていないと言わざるをえません。

しかしながら，前述したマルチメディア関連技術の発達 とともに，近距離の装置間，ボード間の大容量伝送を可能 とする光インタコネクションの研究開発が, 今, 活発化し てきています。光インタコネクションが，すでに広範囲に 行き渡り, かつ進展している電気インタコネクションに対 抗して普及するためには，高スループット性の追及のみな らず，何よりも経済性・低コスト化がポイントとなること は明らかであります。言い替えれば, 光インタコネクショ ンの研究開発は, 現行の製造プロセスへの整合性も含め量 産技術が最も求められる分野であり，工業技術としてのブ レークスルーが直接問われる典型な技術領域とも言えま
す。そのような低コスト化に向けての研究開発, 技術開発 の努力は, 必ずや新しい市場の開拓となって花開くことと なるでしょう。

このような状況の中で, 今年 1 月 19 日, 当·光回路実装 技術委員会（委員長：大阪大学・佐々木孝友教授）の光回 路実装技術研究会（主査：東海大学・三上修教授）が開催 した公開研究会「脚光を浴びる光インタコネクション」で は，100名近い参加者を集め大成功を博しました。このこ とは，まさに光インタコネクション技術が脚光を浴びてい る現状と各社の技術開発意欲をそのまま表していると言っ ても過言ではありません。

今回この公開研究会をもとに, 光インタコネクション特 集として, 選りすぐった論文を集め, 種々の角度から光イ ンタコネクション技術を展望し，またブレークスルーをも たらし得る新しい技術を紹介することを企画いたしまし た。本特集が, 今後の光インタコネクション技術の貴重な 技術展望資料として貢献することを願ってやみません。

最後に，本特集を組むにあたり，お忙しいなか，ご執筆 をご快諾いただきました筆者の方々に心より感謝いたしま すとともに，本特集号の企画編集にご尽力いただきました 編集委員の皆さま, 光回路実装技術委員会の関係各位にお 礼申し上げます。

(1998.5.8.-受理)

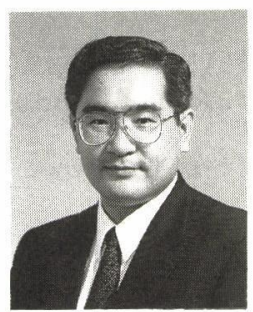

桂 浩輔(かららこうすけ)

昭和 31 年生まれ。昭和 56 年, 電気通信大学大学 院計算機科学専攻修士課程修了。現在, NTT 光エレタトロニクス研究所において, 光インタ コネクション技術掞よび光実装技術の研究開発 に従事。 